\title{
Soil Test Based Fertilizer Prescriptions through Integrated Nutrient Management Using Targeted Yield Approach for Rice-Blackgram Sequence
}

\author{
D. Mounika ${ }^{1^{*}}$, M. Martin Luther ${ }^{1}$, K. Chandra Sekhar ${ }^{1}$, \\ G. Kishore Babu' ${ }^{2}$ and K. Jaya Lalitha ${ }^{3}$ \\ ${ }^{1}$ Department of Agronomy ANGRAU, Guntur, A.P., India \\ ${ }^{2}$ Department of Soil Science and Agricultural Chemistry ANGRAU, Guntur, A.P., India \\ ${ }^{3}$ Department of Crop Physiology and ANGRAU, Guntur, A.P., India \\ *Corresponding author
}

\section{A B S T R A C T}

Keywords

Rice, Targeted yield fertilizer recommendation, Yield and yield attributes, STFR.

Article Info

Accepted:

18 March 2020

Available Online:

10 April 2020
A field experiment was conducted at the Agricultural College farm, Bapatla, during kharif and rabi 2017-18 and 2018-19. The experiment was conducted with variety BPT-5204 in a Randomized Block Design with ten treatments and three replications. The maximum Number of Panicles $\mathrm{m}^{-2}$, total filled grains panicle ${ }^{-1}$, test weight, Grain yield, Straw yield and Harvest Index were recorded with soil test based fertilizer recommendation with $10 \mathrm{t} \mathrm{ha}^{-1}$ FYM application which was at par with soil test based fertilizer recommendation alone and 7.5 tha $^{-1}$ targeted yield recommendation along with FYM ( $\mathrm{T}_{5}$ and $\left.\mathrm{T}_{10}\right)$ and RDF with FYM $\left(\mathrm{T}_{6}\right)$. Grain yield of rice was significantly higher with soil test based fertilizer recommendation with $10 \mathrm{t} \mathrm{ha}^{-1}$ FYM application which was statistically at par with soil test based fertilizer recommendation alone $\left(\mathrm{T}_{2}\right)$ and $7.5 \mathrm{tha}^{-1}$ targeted yield fertilizer recommendation with FYM $\left(\mathrm{T}_{10}\right)$ compared to the rest of the treatments.

\section{Introduction}

Rice is a staple food crop not only in India but also in entire South Asia. Of the total rice (Oryza sativa L.) production in the world, more than $90 \%$ is in Asia. Rice is cultivated in 111 countries of all continents, except
Antarctica. India and China are the leading producers as well as consumers of rice. In India, it is grown in an area of $43.9 \mathrm{~m}$ ha with a production of $99.24 \mathrm{~m} \mathrm{t}$ and productivity of $2494 \mathrm{~kg} \mathrm{ha}^{-1}$. In Andhra Pradesh, it is grown in an area of $2.152 \mathrm{~m}$ ha with a production of $8.05 \mathrm{~m} \mathrm{t}$ and productivity of $3741 \mathrm{~kg} \mathrm{ha}^{-1}$. 
(Anon, 2018). Integrated nutrient management, which entails the maintenance / adjustment of soil fertility to an optimum level for crop productivity to obtain the maximum benefit from all possible sources of plant nutrients. To get more and more yield, farmers inclined to the excess use of chemical fertilizer, but the decision on fertilizer use requires knowledge of the expected crop yield response to nutrient application, which is a function of crop nutrient needs, supply of nutrients from indigenous sources, and the short and long term fate of fertilizer applied. Application of fertilizers by the farmers in the fields without information on soil fertility status and nutrient requirement by the crop causes adverse effects in soil and crop regarding both nutrient toxicity and deficiency either by over use or inadequate use.

\section{Materials and Methods}

A field experiment was conducted at the Agricultural College farm, Bapatla, during kharif and rabi 2017-18 and 2018-19. The experiment was conducted with variety BPT5204 in a Randomized Block Design with ten treatments and three replications. The treatments comprised of, Recommended Dose of Fertilizer $\left(\mathrm{T}_{1}\right)$, Soil test based fertilizer recommendation $\left(\mathrm{T}_{2}\right)$; $\quad$ Targeted yield fertilizer recommendations for 5.5 tons $\mathrm{ha}^{-1}\left(\mathrm{~T}_{3}\right), 6.5 \mathrm{t} \mathrm{ha}^{-1}\left(\mathrm{~T}_{4}\right)$ and $7.5 \mathrm{t} \mathrm{ha}^{-1}\left(\mathrm{~T}_{5}\right)$; Treatment $\mathrm{T}_{1}+\mathrm{FYM} @ 10 \mathrm{t} \mathrm{ha}^{-1}\left(\mathrm{~T}_{6}\right)$; Treatment $\mathrm{T}_{2}+$ FYM @10 t ha ${ }^{-1}\left(\mathrm{~T}_{7}\right)$; Treatment $\mathrm{T}_{3}+$ FYM @ $10 \mathrm{t} \mathrm{ha}^{-1}\left(\mathrm{~T}_{8}\right)$; Treatment $\mathrm{T}_{4}+\mathrm{FYM} @ 10 \mathrm{tha}^{-1}\left(\mathrm{~T}_{9}\right)$; and Treatment $\mathrm{T}_{5}$ + FYM @ $10 \mathrm{tha}^{-1}\left(\mathrm{~T}_{10}\right)$. The experimental soil was clay loam in texture, slightly alkaline in reaction, non-saline, low in available nitrogen, and low in organic carbon, high available phosphorus and potassium. The application of nutrients was done following the soil test based fertilizer recommendations as per the treatment.
Target yield fertilizer recommendations were based on using the target yield equations developed for Krishna Godavari agro ecological region.

By using formulae targeted yield $\left(\mathrm{qha}^{-1}\right)$ equation for kharif- rice: (Anon., 2007)

\begin{tabular}{|l|l|}
\hline$* \mathbf{F N}=2.30 \times \mathbf{T} 0.32 \times \mathbf{S N}$ & $\mathbf{S N}=$ Soil Nitrogen \\
\hline$* \mathbf{F P}_{2} \mathbf{O}_{5}=1.91 \times \mathbf{T}-1.90 \times S P$ & $\mathrm{SP}=$ Soil Phosphorous \\
\hline$* \mathbf{F K}=\mathbf{2 . 2 7} \times \mathbf{T}-\mathbf{0 . 2 7} \times \mathbf{S K}$ & $\mathrm{SK}=$ Soil Potassium \\
\hline
\end{tabular}

Fertilizer schedule during kharif riceduring 2017and 2018 (as per initial soil analysis data)

\begin{tabular}{|c|c|c|}
\hline Treatments & $\begin{array}{c}2017-18 \\
\text { N-P-K } \\
\left(\text { kg ha }^{-1}\right)\end{array}$ & $\begin{array}{l}2018-19 \\
\text { N-P-K } \\
\left(\text { kg ha }^{-1}\right)\end{array}$ \\
\hline$T_{1}$ & $120-60-40$ & $120-60-40$ \\
\hline$T_{2}$ & $156-42-28$ & $156-42-28$ \\
\hline $\mathbf{T}_{3}$ & $80-30-30$ & $70-30-28$ \\
\hline$T_{4}$ & $102-30-52$ & $98-30-50$ \\
\hline $\mathbf{T}_{5}$ & $125-30-75$ & $123-30-73$ \\
\hline $\mathbf{T}_{6}$ & $\begin{array}{c}\mathrm{T}_{1}+\mathrm{FYM} @ 10 \mathrm{t} \\
\mathrm{ha}^{-1}\end{array}$ & $\begin{array}{c}\mathrm{T}_{1}+\mathrm{FYM} @ 10 \mathrm{t} \\
\mathrm{ha}^{-1}\end{array}$ \\
\hline $\mathbf{T}_{7}$ & $\begin{array}{c}\mathrm{T}_{2}+\mathrm{FYM} @ 10 \mathrm{t} \\
\mathrm{ha}^{-1}\end{array}$ & $\begin{array}{c}\mathrm{T}_{2}+\mathrm{FYM} @ 10 \mathrm{t} \\
\mathrm{ha}^{-1}\end{array}$ \\
\hline$T_{8}$ & $\begin{array}{c}\mathrm{T}_{3}+\mathrm{FYM} @ 10 \mathrm{t} \\
\mathrm{ha}^{-1}\end{array}$ & $\begin{array}{c}\mathrm{T}_{3}+\mathrm{FYM} @ 10 \mathrm{t} \\
\mathrm{ha}^{-1}\end{array}$ \\
\hline$T_{9}$ & $\begin{array}{c}\mathrm{T}_{4}+\mathrm{FYM} @ 10 \mathrm{t} \\
\mathrm{ha}^{-1}\end{array}$ & $\begin{array}{c}\mathrm{T}_{4}+\mathrm{FYM} @ 10 \mathrm{t} \\
\mathrm{ha}^{-1}\end{array}$ \\
\hline $\mathbf{T}_{10}$ & $\begin{array}{c}\mathrm{T}_{5}+\mathrm{FYM} @ 10 \mathrm{t} \\
\mathrm{ha}^{-1}\end{array}$ & $\begin{array}{c}\mathrm{T}_{5}+\mathrm{FYM} @ 10 \mathrm{t} \\
\mathrm{ha}^{-1}\end{array}$ \\
\hline
\end{tabular}

\section{Results and Discussion}

A perusal of the data on number of panicles $\mathrm{m}^{-2}$ (Table 1) indicated that it was significantly influenced by the various treatments during two consecutive years and in pooled data.

The highest number of panicles $\mathrm{m}^{-2}$ were observed with STFR with FYM $\left(\mathrm{T}_{7}\right)$ followed by STFR without FYM $\left(\mathrm{T}_{2}\right), \quad 7.5 \mathrm{t} \mathrm{ha}^{-1}$ 
targeted yield with FYM $\left(\mathrm{T}_{10}\right)$ and without FYM $\left(\mathrm{T}_{5}\right)$ compared to rest of the treatments at harvest. Targeted yield fertilizer recommendations except for $7.5 \mathrm{t} \mathrm{ha}^{-1}$ without FYM $\left(\mathrm{T}_{3}, \mathrm{~T}_{4}, \mathrm{~T}_{8}\right.$ and $\left.\mathrm{T}_{9}\right)$ recorded the significantly lower number of panicles $\mathrm{m}^{-2}$ compared to other treatments $\left(\mathrm{T}_{7}, \mathrm{~T}_{2}, \mathrm{~T}_{10}, \mathrm{~T}_{5}\right.$, and $\mathrm{T}_{6}$ ) at harvest. However, differences between these treatments and applications of RDF were not significant during both the years and pooled data. Number of panicles $m$ ${ }^{2}$ recordedwith $7.5 \mathrm{t} \mathrm{ha}^{-1}$ targeted yield fertilizer recommendation $\left(\mathrm{T}_{10}\right)$ with FYM found significantly superior to other targeted yield fertilizer recommendation treatments $\left(\mathrm{T}_{3}, \mathrm{~T}_{4}, \mathrm{~T}_{9}\right.$ and $\left.\mathrm{T}_{8}\right)$ at harvest during 2017 and 2018.

The per cent increase in number of panicles $\mathrm{m}^{-2}$ with STFR fertilizer recommendation with $10 \mathrm{t} \mathrm{ha}^{-1}$ FYM $\left(\mathrm{T}_{7}\right)$, STFR fertilizer recommendation alone $\left(\mathrm{T}_{2}\right)$ was $21.37 \%$, $21.72 \%, 16.20 \% \& 18.62 \%$ and $20.0 \%$, $20.35 \%, 14.73 \% \& 17.19 \%$, over the targeted yield fertilizer recommendation $\mathrm{T}_{3}$, $\mathrm{T}_{4}, \mathrm{~T}_{9}$ and $\mathrm{T}_{8}$ respectively at maturity in pooled data.

Organic manures improve the physical, chemical and biological properties of the soil. These are the sources of all the nutrients required by plants in limited quantities so as to maintain $\mathrm{C}: \mathrm{N}$ ratio in the soil. When these are added to soil along with inorganic fertilizer it increases fertility and productivity of soil. Similar findings are supported by Kandeshwari and Thavaprakash (2016) who reported that extra yields were most probably secured by the addition of organic manure, particularly at the rate of $10 \mathrm{t} \mathrm{ha}^{-1}$ of FYM, along with optimum plant stand. Data on total filled grains panicle ${ }^{-1}$ are presented in (Table 2) at harvest of rice which was significantly affected by soil test and targeted yield based fertilizer recommendation during both the years of experimentation.
At harvest, STFR with $10 \mathrm{t} \mathrm{ha}^{-1}$ FYM $\left(\mathrm{T}_{7}\right)$ and STFR alone $\left(\mathrm{T}_{2}\right)$ recorded significantly maximum number of filled grains panicle $^{-1}$ compared to all other treatments. However the differences in filled grains between the treatments $T_{2}$ and $T_{10}$ were not significant during year 2017 and 2018. Though $5.5 \mathrm{t} \mathrm{ha}^{-1}$ targeted yield fertilizer recommendations $\left(\mathrm{T}_{3}\right)$ recorded lower number of filled grains panicle $^{-1}$, the differences among the rest of the treatments except $T_{7}, T_{2}$ and $T_{10}$ were not statistically significant during the years 2017 and 2018.

The per cent increase in number of filled grains panicle ${ }^{-1}$ with STFR with $10 \mathrm{t} \mathrm{ha}^{-1}$ FYM $\left(\mathrm{T}_{7}\right)$, STFR alone $\left(\mathrm{T}_{2}\right)$ was $18.5 \%, 15.7$ $\%, 15.0 \%$ and $17.5 \%, 14.7,11.7,11.0$ and $13.6 \%$, over the targeted yield fertilizer recommendation $\left(\mathrm{T}_{3}, \mathrm{~T}_{4}, \mathrm{~T}_{9}\right.$ and $\left.\mathrm{T}_{8}\right)$ at harvest during both the years 2017, 2018 and in pooled data respectively.

Increased number of panicles produced higher number of filled grains in the treatments based on soil test recommendations $\left(\mathrm{T}_{7}\right.$ and $\mathrm{T}_{2}$ ) might have ensured adequate nutrient supply particularly $\mathrm{N}$ which inturn reflected on yield attributes of rice. Similar results and opinions were expressed by Dakshina Murthy et al., (2015).

The data (Table 3) pertaining to test weight revealed that test weight was not significantly affected by different nutrient management practices with application of FYM during both the years of experimentation and in pooled data.

However, among the treatments, soil test based fertilizer scheduling with application of $10 \mathrm{t} \mathrm{ha}^{-1}$ FYM recorded higher test weight numerically followed by STFR alone when compared to other treatments during both years. Adequate supply of all nutrients might have contributed to proper development of 
grain after flowering, which in turn might have favored the higher weight of the grain.

The per cent increase in test weight with STFR fertilizer recommendation with $10 \mathrm{t}$ ha

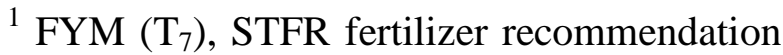
alone $\left(\mathrm{T}_{2}\right)$ was $8.62 \%, 8.04 \%, 6.89 \%$ and $8.04 \% ; 4.79,4.17,2.99$ and $2.39 \%$, over the targeted yield fertilizer recommendation $\left(\mathrm{T}_{3}\right.$, $\mathrm{T}_{4}, \quad \mathrm{~T}_{9}$ and $\mathrm{T}_{8}$ ) at harvest during both the years 2017, 2018 and in pooled data respectively.

Data pertaining to grain yield (Table 4) indicated that STFR with $10 \mathrm{t} \mathrm{ha}^{-1} \mathrm{FYM}\left(\mathrm{T}_{7}\right)$, followed by $T_{2}$ produced significantly higher grain yield compared to rest of the treatments. However, they were on par with that of $\mathrm{T}_{10}$ in the year 2018 and $T_{10}$ and $T_{5}$ in 2017. The higher yields recorded with STFR+ FYM $\left(\mathrm{T}_{7}\right)$ were 5117,6023 and $5570 \mathrm{~kg} \mathrm{ha}^{-1}$ which were statistically on par with STFR application alone $\left(\mathrm{T}_{2}\right)$ i.e, 5099, 5805 and $5452 \mathrm{~kg} \mathrm{ha}^{-1}$ during $1^{\text {st }}$ and $2^{\text {nd }}$ years and in pooled data respectively.

Increased use of fertilizers in the fields without information on soil fertility status and nutrient requirement by crop causes undesirable effects on soil and crop. Management of site specific variability in nutrient supply is a key strategy to overcome the imbalances in fertilizer applications. Soil test based application of plant nutrients facilitates the exact application of nutrients in proportion to the extent of the deficiency of a particular nutrient. The lowest yields observed with the targeted yield fertilizer recommendation@5.5 $\mathrm{t} \mathrm{ha}^{-1}$ alone $\left(\mathrm{T}_{3}\right)$ followed by other targeted yield fertilizer recommendation treatments $\left(\mathrm{T}_{4}, \mathrm{~T}_{8}\right.$ and $\left.\mathrm{T}_{9}\right)$ were significantly inferior compared with other treatments.

However, differences among the treatments based on targeted yield fertilizer recommendation treatments $\mathrm{T}_{4}, \mathrm{~T}_{3}, \mathrm{~T}_{8}$ and $\mathrm{T}_{9}$ and RDF $\left(\mathrm{T}_{1}\right)$ were not statistically significant.

Grain yield recorded with $7.5 \mathrm{t} \mathrm{ha}^{-1}$ targeted yield fertilizer recommendation with FYM $\left(\mathrm{T}_{10}\right)$ found significantly superior over the targeted yield fertilizer recommendation treatments $\left(\mathrm{T}_{3}, \mathrm{~T}_{4}, \mathrm{~T}_{8}\right.$ and $\left.\mathrm{T}_{9}\right)$ at harvest during the year 2017 and in pooled data. The differences were not significant among the treatments $\mathrm{T}_{10}, \mathrm{~T}_{9}$ and $\mathrm{T}_{4}$.

Soil test based fertilizer recommendation regulate on the reason that nutrient requirement of the crop minus nutrient supplied by soil should be the amount of fertilizer needed. It requires estimating the amount of nutrient removed by a crop for a certain yield level and the contribution of nutrient from the soil source, then finally the amount of fertilizer to be added to meet the requirement of crop is calculated considering the efficiency of fertilizer. This approach provides the foundation for optimum resources utilization and balanced nutrient management.

The per cent increase in grain yield with STFR recommendation with $10 \mathrm{t} \mathrm{ha}^{-1}$ FYM $\left(\mathrm{T}_{7}\right)$, STFR fertilizer recommendation alone $\left(\mathrm{T}_{2}\right)$ was $18.9 \%, 14.4 \%, 13.6 \%$ and $17.2 \%$; $17.1 \%, 12.6 \%, 11.8 \%$ and $15.4 \%$ over the targeted yield fertilizer recommendation $\left(\mathrm{T}_{3}\right.$, $\mathrm{T}_{4}, \quad \mathrm{~T}_{9}$ and $\mathrm{T}_{8}$ ) at harvest during both the years 2017, 2018 and in pooled data, respectively. Soil testing provides sound information about the fertility and productivity of soils.

The effectiveness of soil test must be judged from actual field performance. This facilitates the farmers to make the most profitable use of the costly inputs in farming. These findings are in corroboration with that of Bera et al., (2006). 
Data pertaining to straw yield of rice (Table 4) indicated that the straw yields recorded were higher in the $2^{\text {nd }}$ year as compared to that of $1^{\text {st }}$ year of study due to higher initial availability of NPK and organic carbon status in second year field experiment.

Among the treatments, STFR with $10 \mathrm{tha}^{-1}$ FYM $\left(\mathrm{T}_{7}\right)$, recorded significantly higher straw yield of 6100, 6437 and $6268 \mathrm{~kg} \mathrm{ha}^{-1}$ during $1^{\text {st }}$ year, $2^{\text {nd }}$ year and pooled data, respectively; and it was statistically on a par with that of rest of the treatments except the treatments $T_{3}$ and $\mathrm{T}_{8}$ during both the years and pooled data.

This might be due to stimulated vegetative growth as evidenced through higher dry matter accumulation per unit area @ 12757 $\mathrm{kg} \mathrm{ha}{ }^{-1}$. On account of adequate and prolonged supply of essential nutrients, slow mineralization besides improving soil health and greater availability of nutrients in soil that improved soil environment with higher root penetration leading to better absorption of moisture and nutrients and thus reflected in higher straw yield.

Targeted yield fertilizer recommendation except $7.5 \mathrm{t} \mathrm{ha}^{-1}$ with or without FYM $\left(\mathrm{T}_{5}, \mathrm{~T}_{4}\right.$, $\mathrm{T}_{8}$ and $\mathrm{T}_{9}$ ) recorded significantly the lowest straw yield compared to other treatments at maturity. However, differences between these treatments and applications of RDF $\left(\mathrm{T}_{1}\right)$ were not statistically significant during both years of experimentation 2017, 2018 and pooled data. Similar trend was observed during both the years of study.

The lower straw yields recorded with these treatments might be due to lower drymatter production during plant vegetative growth phase owing to inadequate supply of nutrients to crop growth.

The per cent increase in straw yield with STFR fertilizer recommendation with 10 $\mathrm{t} \mathrm{ha}^{-1}$ FYM $\left(\mathrm{T}_{7}\right)$, STFR fertilizer recommendation alone $\left(\mathrm{T}_{2}\right)$ was $21.3 \%, 10.1$ $\%, 9.9 \%$ and $201 \% ; 20.32 \%, 9.02 \%, 8.81 \%$ and $19.06 \%$ over the targeted yield fertilizer recommendation $\left(\mathrm{T}_{3}, \mathrm{~T}_{4}, \mathrm{~T}_{9}\right.$ and $\left.\mathrm{T}_{8}\right)$ at harvest during both the years 2017, 2018 and pooled data respectively. A few other researchers noticed the similar results (Sarkar et al., 2014 and Jemila et al., 2017).

The data (Table 4) pertaining to harvest index revealed that harvest index was not influenced significantly by various nutrient management treatments during both the years of experimentation and in pooled data .

Higher harvest index values were observed with conjunctive use of FYM with other treatments than those of without FYM. However, among the treatments, targeted yield $\quad\left(5.5 \quad \mathrm{t} \quad \mathrm{ha}^{-1}\right)$ based fertilizer recommendation with $10 \mathrm{t} \mathrm{ha}^{-1}$ FYM recorded the higher harvest index numerically followed by STFR application with FYM $\left(\mathrm{T}_{6}\right)$ when compared to other treatments during both years.

The increase in grain yield under combined application of FYM manure along with inorganic fertilizers has led to higher harvest index as documented by Kandeshwari and Thavaprakaash (2016). 
Table.1 Total number of panicles $\mathrm{m}^{-2}$ of kharif rice as influenced by site - specific nutrient management in rice-blackgram sequence during kharif 2017-18, 2018-19 and pooled data

\begin{tabular}{|c|c|c|c|}
\hline Treatments & 2017-18 & 2018-19 & Pooled data \\
\hline $\mathrm{T}_{1^{-}} \quad$ Recommended dose of fertilizer (RDF) $120-60-40 \mathrm{~kg} \mathrm{ha}^{-1}$ & 249.1 & 266.7 & 257.9 \\
\hline $\mathrm{T}_{2^{-}} \quad$ Soil test based fertilizer recommendation (STFR) & 271.8 & 299.3 & 285.6 \\
\hline $\mathrm{T}_{3^{-}} \quad$ Targeted yield fertilizer recommendation for $5.5 \mathrm{t} \mathrm{ha}^{-1}$ (TYFR) & 227.6 & 228.7 & 228.1 \\
\hline $\mathrm{T}_{4^{-}} \quad$ Targeted yield fertilizer recommendation for $6.5 \mathrm{t} \mathrm{ha}^{-1}$ (TYFR) & 238.0 & 216.3 & 227.2 \\
\hline $\mathrm{T}_{5^{-}} \quad$ Targeted yield fertilizer recommendation for $7.5 \mathrm{t} \mathrm{ha}^{-1}$ (TYFR) & 254.9 & 280.0 & 267.5 \\
\hline $\mathrm{T}_{6^{-}} \quad \mathrm{T}_{1}+\mathrm{FYM} @ 10 \mathrm{t} \mathrm{ha}^{-1}$ & 250.7 & 275.0 & 262.9 \\
\hline $\mathrm{T}_{7^{-}} \quad \mathrm{T}_{2}+\mathrm{FYM} @ 10 \mathrm{t} \mathrm{ha}^{-1}$ & 277.2 & 302.9 & 290.1 \\
\hline $\mathrm{T}_{8^{-}} \quad \mathrm{T}_{3}+\mathrm{FYM} @ 10 \mathrm{tha}^{-1}$ & 236.4 & 237.4 & 236.9 \\
\hline $\mathrm{T}_{9^{-}} \quad \mathrm{T}_{4}+\mathrm{FYM} @ 10 \mathrm{tha}^{-1}$ & 242.6 & 244.4 & 243.5 \\
\hline $\mathrm{T}_{10^{-}} \mathrm{T}_{5}+\mathrm{FYM} @ 10 \mathrm{t} \mathrm{ha}^{-1}$ & 263.6 & 283.3 & 273.5 \\
\hline $\mathrm{SEm} \pm$ & 4.86 & 14.71 & 8.29 \\
\hline $\mathrm{CD}(\mathrm{p}=0.05)$ & 14.43 & 43.70 & 24.63 \\
\hline $\mathrm{CV}(\%)$ & 3.3 & 9.6 & 5.5 \\
\hline
\end{tabular}

Table.2 Number of filled grains panicle ${ }^{-1}$ of kharif rice as influenced by site - specific nutrient management in rice-blackgram sequence during kharif 2017-18, 2018-19 and pooled data

\begin{tabular}{|c|c|c|c|}
\hline Treatments & 2017-18 & 2018-19 & Pooled data \\
\hline$T_{1}$-Recommended dose of fertilizer (RDF) $120-60-40 \mathrm{~kg} \mathrm{ha}^{-1}$ & 143.0 & 157.3 & 150.2 \\
\hline $\mathbf{T}_{2}$ - Soil test based fertilizer recommendation (STFR) & 164.2 & 169.0 & 166.6 \\
\hline $\mathrm{T}_{3}$-Targeted yield fertilizer recommendation for $5.5 \mathrm{t} \mathrm{ha}^{-1}$ (TYFR) & 132.6 & 151.7 & 142.1 \\
\hline $\mathrm{T}_{4^{-}}$Targeted yield fertilizer recommendation for $6.5 \mathrm{t} \mathrm{ha}^{-1}$ (TYFR) & 141.3 & 153.0 & 147.1 \\
\hline$T_{5^{-}}$Targeted yield fertilizer recommendation for $7.5 \mathrm{t} \mathrm{ha}^{-1}$ (TYFR) & 147.3 & 162.9 & 155.1 \\
\hline $\mathrm{T}_{6}-\mathrm{T}_{1}+\mathrm{FYMM} @ 10 \mathrm{t} \mathrm{ha}{ }^{-1}$ & 146.0 & 161.2 & 153.6 \\
\hline$T_{7}-T_{2}+F Y M @ 10 t^{-1}$ & 169.0 & 179.8 & 174.4 \\
\hline $\mathrm{T}_{8^{-}} \mathrm{T}_{3}+\mathrm{FYM} @ 10 \mathrm{tha}^{-1}$ & 135.2 & 152.5 & 143.9 \\
\hline $\mathrm{T}_{9}-\mathrm{T}_{4}+\mathrm{FYM} @ 10 \mathrm{tha}^{-1}$ & 142.1 & 154.3 & 148.2 \\
\hline $\mathrm{T}_{10^{-}} \mathrm{T}_{5}+\mathrm{FYM} @ 10 \mathrm{tha}^{-1}$ & 149.9 & 166.8 & 158.4 \\
\hline SEm \pm & 5.40 & 4.95 & 3.62 \\
\hline $\mathrm{CD}(\mathbf{p}=0.05)$ & 16.04 & 14.71 & 10.78 \\
\hline $\mathrm{CV}(\%)$ & 6.36 & 5.33 & 4.08 \\
\hline
\end{tabular}


Table.3 Test weight (g/1000 grain) at harvest of kharif rice as influenced by site - specific nutrient management in Rice - blackgram sequence during kharif 2017-18, 2018-19 and pooled data

\begin{tabular}{|c|c|c|c|}
\hline Treatments & 2017-18 & 2018-19 & Pooled data \\
\hline$T_{1^{-}}$Recommended dose of fertilizer (RDF) $120-60-40 \mathrm{~kg} \mathrm{ha}^{-1}$ & 15.9 & 16.6 & 16.2 \\
\hline$T_{2^{-}} \quad$ Soil test based fertilizer recommendation (STFR) & 16.3 & 17.0 & 16.7 \\
\hline $\mathrm{T}_{3^{-}} \quad$ Targeted yield fertilizer recommendation for $5.5 \mathrm{t} \mathrm{ha}^{-1}$ (TYFR) & 15.6 & 16.3 & 15.9 \\
\hline$T_{4^{-}} \quad$ Targeted yield fertilizer recommendation for $6.5 \mathrm{t} \mathrm{ha}^{-1}$ (TYFR) & 15.7 & 16.4 & 16.0 \\
\hline $\mathrm{T}_{5^{-}} \quad$ Targeted yield fertilizer recommendation for $7.5 \mathrm{t} \mathrm{ha}^{-1}$ (TYFR) & 16.2 & 16.9 & 16.5 \\
\hline $\mathrm{T}_{6^{-}} \quad \mathrm{T}_{1}+\mathrm{FYM} @ 10 \mathrm{t} \mathrm{ha}^{-1}$ & 16.1 & 16.8 & 16.5 \\
\hline $\mathrm{T}_{7^{-}} \quad \mathrm{T}_{2}+\mathrm{FYM} @ 10 \mathrm{tha}^{-1}$ & 17.0 & 17.7 & 17.4 \\
\hline $\mathrm{T}_{8^{-}} \quad \mathrm{T}_{3}+\mathrm{FYM} @ 10 \mathrm{t} \mathrm{ha}^{-1}$ & 15.6 & 16.3 & 16.0 \\
\hline $\mathrm{T}_{9^{-}} \quad \mathrm{T}_{4}+\mathrm{FYM} @ 10 \mathrm{t} \mathrm{ha}^{-1}$ & 15.8 & 16.5 & 16.2 \\
\hline $\mathrm{T}_{10^{-}} \quad \mathrm{T}_{5}+\mathrm{FYM} @ 10 \mathrm{tha}^{-1}$ & 16.3 & 17.0 & 16.6 \\
\hline SEm \pm & 0.53 & 0.45 & 0.49 \\
\hline$C D(p=0.05)$ & NS & NS & NS \\
\hline CV $(\%)$ & 5.7 & 4.6 & 5.1 \\
\hline
\end{tabular}

Table.4 Grain yield $\left(\mathrm{kg} \mathrm{ha}^{-1}\right)$, straw yield $\left(\mathrm{kg} \mathrm{ha}^{-1}\right)$ and harvest index $(\%)$ of rice as influenced by site - specific nutrient management in rice-blackgram sequence during kharif 2017-18, 2018-19 and pooled data

\begin{tabular}{|c|c|c|c|c|c|c|c|c|c|}
\hline \multirow[t]{2}{*}{ Treatments } & \multicolumn{3}{|c|}{ 2017-18 } & \multicolumn{3}{|c|}{ 2018-19 } & \multicolumn{3}{|c|}{ Pooled data } \\
\hline & $\begin{array}{c}\text { Grain } \\
\text { yield }\end{array}$ & $\begin{array}{c}\text { Straw } \\
\text { yield }\end{array}$ & $\begin{array}{c}\text { Harvest } \\
\text { index }\end{array}$ & $\begin{array}{l}\text { Grain } \\
\text { yield }\end{array}$ & $\begin{array}{c}\text { Straw } \\
\text { yield }\end{array}$ & $\begin{array}{c}\text { Harvest } \\
\text { index }\end{array}$ & $\begin{array}{c}\text { Grain } \\
\text { yield }\end{array}$ & $\begin{array}{c}\text { Straw } \\
\text { yield }\end{array}$ & $\begin{array}{c}\text { Harvest } \\
\text { index }\end{array}$ \\
\hline$T_{1^{-}}$Recommended dose of fertilizer (RDF) $120-60-40 \mathrm{~kg} \mathrm{ha}^{-1}$ & 4450 & 5640 & 44.19 & 5236 & 5806 & 47.5 & 4843 & 5722 & 45.96 \\
\hline $\mathbf{T}_{2-}$ - Soil test based fertilizer recommendation (STFR) & 5099 & 6175 & 45.29 & 5805 & 6214 & 48.3 & 5452 & 6194 & 46.86 \\
\hline $\mathrm{T}_{3}$-Targeted yield fertilizer recommendation for $5.5 \mathrm{t} \mathrm{ha}^{-1}$ (TYFR) & 4234 & 4933 & 46.41 & 4800 & 4937 & 49.4 & 4517 & 4935 & 48.02 \\
\hline $\mathrm{T}_{4^{-}}$Targeted yield fertilizer recommendation for $6.5 \mathrm{t} \mathrm{ha}^{-1}$ (TYFR) & 4370 & 5577 & 43.93 & 5163 & 5693 & 47.5 & 4766 & 5635 & 45.83 \\
\hline$T_{5^{-}}$Targeted yield fertilizer recommendation for $7.5 \mathrm{t} \mathrm{ha}^{-1}$ (TYFR) & 4831 & 5959 & 45.00 & 5540 & 6013 & 47.9 & 5186 & 5986 & 46.48 \\
\hline $\mathbf{T}_{6^{-}}-\mathrm{T}_{1}+\mathrm{FYM} @ 10 \mathrm{t} \mathrm{ha}^{-1}$ & 4667 & 5700 & 45.02 & 5346 & 5900 & 47.5 & 5007 & 5800 & 46.32 \\
\hline $\mathbf{T}_{7^{-}} \mathbf{T}_{2}+\mathrm{FYM} @ 10 \mathrm{tha}^{-1}$ & 5117 & 6100 & 45.54 & 6023 & 6437 & 48.3 & 5570 & 6268 & 47.03 \\
\hline $\mathrm{T}_{8^{-}} \mathrm{T}_{3}+\mathrm{FYM} @ 10 \mathrm{t} \mathrm{ha}^{-1}$ & 4358 & 5005 & 46.56 & 4870 & 5017 & 49.4 & 4614 & 5010 & 47.97 \\
\hline $\mathrm{T}_{9^{-}} \quad \mathrm{T}_{4}+\mathrm{FYM} @ 10 \mathrm{tha}^{-1}$ & 4396 & 5590 & 44.19 & 5226 & 5707 & 47.9 & 4811 & 5648 & 46.15 \\
\hline$T_{10^{-}} T_{5}+F Y M @ 10 t h^{-1}$ & 4876 & 6014 & 44.78 & 5614 & 6126 & 48.0 & 5245 & 6069 & 46.43 \\
\hline SEm \pm & 141.2 & 261.3 & 1.37 & 157.1 & 221.9 & 1.55 & 108.92 & 193.57 & 1.13 \\
\hline CD $(p=0.05)$ & 419.2 & 776.4 & NS & 466.9 & 659.2 & NS & 323.6 & 575.1 & NS \\
\hline CV (\%) & 5.2 & 7.9 & 5.2 & 5.0 & 6.6 & 5.59 & 3.77 & 5.8 & 4.20 \\
\hline
\end{tabular}


Thus based on the maximum Number of Panicles $\mathrm{m}^{-2}$, total filled grains panicle ${ }^{-1}$, test weight, Grain yield, Straw yield and Harvest Index it can be recommended to go for up to soil test based fertilizer recommendation with $10 \mathrm{t} \mathrm{ha}^{-1}$ FYM application (156-42-28 kg NPK ha ${ }^{-1}$ ), applied. Among the treatments with soil test based fertilizer recommendation with $10 \mathrm{t} \mathrm{ha}^{-1}$ FYM application which was at par with soil test based fertilizer recommendation alone and $7.5 \mathrm{tha}^{-1}$ targeted yield recommendation along with FYM $\left(\mathrm{T}_{5}\right.$ and $\mathrm{T}_{10}$ ), and RDF with FYM $\left(\mathrm{T}_{6}\right)$.

Whereas targeted yield recommendation 5.5 and $6.5 \mathrm{t} \mathrm{ha}^{-1}\left(\mathrm{~T}_{3}\right.$ and $\left.\mathrm{T}_{4}\right)$ found with significantly lower the maximum Number of Panicles $\mathrm{m}^{-2}$, total filled grains panicle ${ }^{-1}$, test weight, Grain yield, Straw yield and Harvest Index compared to the rest of treatments during both the years of study.

\section{References}

Anonymous, 2007. Soil test based fertilizer application. All India Coordinated Research Project for Investigations on Soil Test Crop Response Correlation (AICRP) Hyderabad Centre, Indian council of Agricultural Research, New Delhi, ANGRAU, Hyderabad and Department of Agriculture, A.P. pp. 60. Anonymous, 2018. Report on area, production and productivity of rice. Ministry of Agriculture, Govt of India.

Bera, R., Seal, A., Bhattacharyya, P., Das, T.H., Sarkar, D., Kangjoo, K. 2006. Targeted yield concept and framework of fertilizer recommendation in irrigated rice domains of subtropical India. Journal of Zhejiang University Science. 7(12):963-968.

Dakshina Murthy, K.M., Rao, U.A., Vijay, D and Sridhar, T.V. 2015. Effect of levels of nitrogen, phosphorus and potassium on performance of rice. Indian Journal of Agricultural Research. 49 (1): 83-87.

Jemila, C., Bakiyathusaliha, B and Udayakumar, S. 2017. Evaluating the effect of phosphatic fertilizer on soil and plant $\mathrm{P}$ availability and maximizing rice crop yield. Oryza. 54 (3): 305-313.

Kandeshwari, $\mathrm{M}$ and Thavaprakaash, N. 2016. Influence of integrated nutrient management practices on yield and nutrient uptake in rice under system of rice intensification. International Journal of Agricultural Science and Research. 6 (2): 123-130.

Sarkar, S., Mandal, M and Das D.K. 2014. Effect of integrated application of reen manure and biofertilisers on soil fertility in rice-pea cropping system. Environment and Ecology. 32 (3): 1010-1015.

\section{How to cite this article:}

Mounika, D., M. Martin Luther, K. Chandra Sekhar, G. Kishore Babu and Jaya Lalitha, K. 2020. Soil Test Based Fertilizer Prescriptions through Integrated Nutrient Management Using Targeted Yield Approach for Rice-Blackgram Sequence. Int.J.Curr.Microbiol.App.Sci. 9(04): 2103-2110. doi: https://doi.org/10.20546/ijcmas.2020.904.253 